\title{
The emergence of the determiner in the Dutch NP*
}

\author{
FREEK VAN DE VELDE
}

\section{Abstract}

This article inquires into the diachrony of the determiner in Dutch. First, it is argued that the determiner is an emergent syntactic category, and that it must be consequently excluded from universal grammar. Second, it is argued that languages that do have a determiner slot in the NP differ considerably with regard to which lexemes they allow in this function. On the basis of these two observations, an in depth usage-based analysis of the emergence of the Dutch determiner is undertaken. It seems that over the centuries, the determiner projection consolidates its position in Dutch. It first cropped up in Old Dutch, and was further elaborated in Middle Dutch, Modern Dutch and Present-day Dutch by the recruitment of ever new slotfillers. Difficulties in the demarcation of the determiner phrase and the notoriously elusive syntax of some adjectives are claimed to be due to diachronic instability: what is e.g., conveniently but somewhat misleadingly called postdeterminers, can be argued to be an instable syntactic category that represents an intermediate stage in the diachronic process. Evidence will be drawn from (quantitative) corpus inquiry.

\section{Introduction}

This article is organized as follows: Section 2 is devoted to the nature of the determiner and its position in the description of the NP. It is argued that the assumption of a universal determiner position in NPs, as often assumed in contemporary linguistic theories, meets problems in languages without overt determiners. The same problems occur with previous stages of languages that presently have an elaborate determiner complex, like English or Dutch. The solution proposed here is to regard the determiner function as an emergent category, which is gradually consolidated over the centuries. In Section 3 it is investigated when the Dutch NP acquired 
a determiner position. In Section 4 it will be argued that after its emergence, the Dutch determiner continues to accrue its membership by the recruitment of more and more slotfillers. In Section 5 the theoretical relevance of the diachronic observations is discussed, and Section 6 rounds off with the conclusions.

The claims that are put forward in the subsequent sections are substantiated by corpus inquiry. Made-up examples are avoided, in keeping with the usage-based approach followed in this paper (see e.g., Barlow and Kemmer 2000; Tummers et al. 2005). Various corpora have been consulted to obtain data. Of these, one corpus is used for statistical analysis. It consists of material from the Woordenboek der Nederlandsche Taal (WNT), which spans the 16th to 20th centuries, comprising about 1,663,000 different citations (see Moerdijk 1998), with geographically and stylistically diverse material. For frequent words (e.g., possessive pronouns, Section 4.1) only a subsection of the dictionary has been used. Details will be provided at the appropriate place in the text. The results, which figure in Tables 1 to 5 , have been analyzed with the aid of the Abundantia Verborum software (Speelman 1997). The other corpora have been consulted "anecdotally", that is: the results are not statistically analyzed. These corpora include both historical and synchronic material and have a broad geographic and stylistic coverage so as to warrant their representativity. For the historical data, I have used the Middelnederlandsch Wordenboek (MNW) (see Appendix), and the ample material gathered in the multivolumed Geschiedenis van de Nederlandse Syntaxis (van der Horst 2008). Present-day Dutch examples are obtained from the 38 million word corpus of INL (see Appendix) and the Internet (explored by Google queries). English examples are taken from the Oxford English Dictionary (OED) and the Internet. Google-search examples are followed by $(\mathrm{G})$.

\section{Determiners}

\subsection{The noun phrase}

In English, nouns are often accompanied by various dependents. In the example under (1), the noun novel is joined by the article $a$ and the adjective lousy.

(1) I personally thought it was a lousy novel. (G)

As is well known, these dependents behave syntactically very differently. To begin with, the adjective but not the article can be discarded without 
damaging the grammaticality. Second, the use of an adjective does not preclude the use of another adjective, whereas the article is mutually exclusive with other articles and pronouns. Third, the article always precedes the adjective. Upon closer inspection dependents of the noun seem to fall into (at least) two groups: those behaving more or less like the article, and those behaving more or less like the adjective. The former are often called determiners, and the latter adjuncts. ${ }^{1}$ Additional support for this distinction is that the syntactic differences correlate with semantic differences: determiners deal with functional properties like definiteness, whereas adjuncts deal with lexical semantics. Noun phrases can then be assumed to have the following structure: ${ }^{2}$

$$
[\ldots \mathrm{D} \ldots[\ldots \mathrm{A} \ldots[\ldots \mathrm{N} \ldots]]]_{\mathrm{NP}}
$$

A distinction should be made between abstract FUNCTIONS or lexically underspecified slots on the one hand, and concrete lexemes or lexically specific words on the other. The $D, A$ and $N$ symbols in (2) stand for functions (determiner, adjunct and head, respectively), which can be fulfilled by different kinds of word classes: the D-position can be occupied by articles, (attributive) pronouns and even phrasal structures like genitives, e.g., these old men's death $(\mathrm{G})$; the A-position can be occupied by adjectives, participles, and phrasal or clausal elements as in a not all too subtle hint $(\mathrm{G})$ or a 'don't hate Ronaldo, hate Rooney instead' piece $(\mathrm{G})$; the N-position is occupied by nouns, although it could be argued that in $\mathrm{NPs}$ like the poor $(\mathrm{G})$ the $\mathrm{N}$ position is taken up by an adjective.

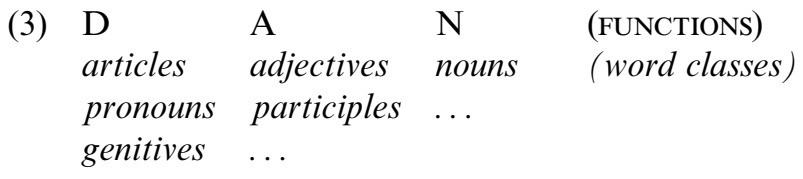

Word classes and functions are often confused: the term determiner is often used for both the slot and the slotfiller. The same confusion arises when adjectives that are used in the $\mathrm{N}$-position, like in the poor, are referred to as "substantivized adjectives", implying that they are really nouns. In this paper, determiner designates a function in the NP, not a word class. To generalize over the various word classes that can be used in determiner function, the term determinatives is used, as in Payne and Huddleston (2002: 330, 355). A similar distinction will be made between adjuncts and modifiers: the term adjunct is reserved for the function in the $\mathrm{NP}$; the term modifier is used as a cover term for those lexemes that can fulfill the role of an adjunct. ${ }^{3}$ Summarizing: adjuncts and determiners are slots in the NP; modifiers and determinatives are slotfillers. 
Two main claims will be defended in this paper:

(4) The determiner position was absent in Proto-Germanic and did not crop up until the Old Dutch period.

(5) Since its emergence in Old Dutch, the determiner position has recruited more and more adjectives and pronouns as slotfillers (determinatives), a still unfinished process in Present-day Dutch.

The claim in (4) questions the idea upheld in many linguistic theories that all languages (or language stages, for that matter) have a determiner projection. The claim in (5) is not entirely unfamiliar in grammaticalization theory, but it will be shown that it involves some lesser known elements (e.g., demonstrative manner adjectives, anaphoric adjectives).

\subsection{Determiners and how to distinguish them from adjuncts}

In formal grammar, the determiner D forms a functional shell (DP) around the NP shell, which — much like the IP (or TP) and CP shells around VP - can express various functional notions, like definiteness, specificity, deixis, number, gender and so on (Bernstein 2001). Obviously, there is variation in what determiners happen to express in various languages around the world. I give two examples: (i) Determiners expressing number (singular vs. plural) are found in French, but hardly in English, where number is normally expressed by the noun (Delfitto and Schroten 1991). (ii) What is expressed in one determiner in Dutch may be spread over two determiners in Hungarian (Szabolcsi 1987).

This kind of variation is not as innocent as it may seem. It is not immediately clear on what grounds one should decide whether an adnominal dependent in a given language or language stage is in fact a determinative or a modifier that is conveniently ("parasitically") used for expressing definiteness, deixis etc. Consider for instance the situation in ProtoGermanic, where (in)definiteness is commonly believed to be expressed by the difference between strong and weak flexion on adjectives: weak adjectives signaled definiteness. Only later, in Old English, this function passed on to the article (see Traugott 1992: 171). Should these weakly declined adjectives be considered determinatives then? The same objections adhere to NPs without overt determiners in languages like Latin or Russian (Longobardi 2001: 584). In such languages, bare NPs with singular count nouns are widely attested in argument position both with definite and with indefinite interpretation. There seem to be no determinatives. It may then reasonably be questioned whether these languages really have a DP projection. 
As appealing as the determiner concept may be at first sight, diagnostic tests for determinerhood are often lacking in theoretical and descriptive grammars. This is illustrated by the fact that grammars disagree about which elements can take the determiner position in English. Sometimes numerals (one, two, many, a lot of etc.) are included; sometimes they are not. Moreover, determiners are considered to be mutually exclusive in Present-day English, but this implies that every is not a determiner, at least when it occurs in combination with a possessive pronoun or genitive, as in John's every word (Szabolcsi 1987: 170; Payne and Huddleston 2002: 379). Linear order is another criterion that is used to set off adjectives from determiners, but the observation that such can occur both before and after a determiner complicates its classification.

To account for all these demarcation difficulties, various solutions have been proposed. A first solution is to distinguish several functional projections above and below the DP. This can easily lead to rather dubious proliferations of functional projections: QP, DP, FP, KP, NumP, GenP etc. This practice has been adopted in quite some publications by formal linguists (see e.g., Coene and D'hulst 2003 for an overview). A second solution is to assume that many in many a book $(\mathrm{G})$ fills another slot than in the many books (G) (see Payne and Huddleston 2002). However, this is an ad hoc solution. It leaves unexplained why we do find many a book (G), but not few a book or some a book. The slotfilling capacities of a lexeme seem to be arbitrary to a certain extent. Another solution is to subdivide the determiner category in predeterminers, determiners and postdeterminers (Quirk et al. 1985: 253-264), with postdeterminers functioning as a hinge between the determiner and the adjuncts (Halliday 1994; Davidse 2000). This solution is not entirely satisfactory either. It is not clear, for instance, whether such is a determiner, as it is mutually exclusive with the definite article, whether it is a predeterminer, as it occurs in front of the indefinite article, or whether it is a postdeterminer, as it occurs after some and any (Denison 2006: 284). A fourth solution is to treat the determiner category as a prototype, with central and peripheral instances (Plank 1992; Denison 2006). A fifth, more radical solution is put forward in Emergent Grammar (Hopper 1987) and the literature on grammaticalization (Hopper and Traugott 2003; Bybee 2007): determiners, like all other kinds of syntactic categories are taken to be epiphenomenal entities, rooted in discourse and ipso facto subject to variation across and within languages. They can be grammaticalized to a higher or lesser degree.

The different solutions just mentioned are ordered from "formal" to "functional". The functional approaches of Denison, Hopper, Bybee and Traugott can be argued to be the least preconceived in that they insist on evidence in the surface structure for the postulation of a determiner in a 
given language or language stage. I shall follow this line of thought, and only assume determiners in language stages where there is material evidence for them. What we need then, is good criteria to distinguish the separate slots.

What are the characteristics of the determiner? Several properties have been proposed. On the semantic side, the determiner always seems to deal with such functional notions as definiteness, referentiality, specificity and identifiability. Elements that have "specialized" in expressing these functions (i.e., that do not express other meanings like color, size etc.), like articles, are generally considered fillers of the determiner slot (Pullum and Huddleston 2002: 538). This yields the following criterion:

(6) Criterion I

When a language has a specialized part of speech (an article), exclusively expressing definiteness, referentiality, specificity, or identifiability, any item of this class is a determinative.

On the syntactic side, undisputed determiners are often characterized by complementary distribution. The use of one precludes the other. A second criterion may then be:

(7) Criterion II

When a language has various adnominal elements entailing (in)definiteness, (un)specificity, referentiality or identifiability, and these elements stand in complementary distribution, they may be considered determinatives.

Apart from their complementary distribution, determiners are also often obligatory, at least in NPs functioning as an argument in a clause. Adjuncts are normally not obligatory, so that the following criterion can be stated:

(8) Criterion III

When a language uses an obligatory element for the expression of definiteness etc., these elements may be considered determinatives.

Another property of determiners is that they do not easily appear as a predicate $^{4}$, probably because the property they express (definiteness and so on) is functional, rather than lexical, does not contribute to the denotation and is therefore hard to explicitly ascribe to a noun. ${ }^{5}$ Put in a third criterion:

(9) Criterion IV

If an adnominal element can act as a predicate, it is not a determinative. 
Next, the determiner is often claimed to occupy the far left position in the NP, due to its scopal properties. In its naive form, this claim is falsified by the observation that the determiner may be preceded by what is conveniently called the "predeterminer" and the "peripheral modifier" (Payne and Huddleston 2002: 433-439). Yet, relative position may still tell us something about determiner status:

(10) Criterion v

If an adnominal dependent occurs to the right of an element that is not a determiner, but an adjunct, it is not a determiner itself.

The latter criterion is perhaps not entirely watertight: in some cases, a plain adjective indeed precedes the article, as in so beautiful a daughter (Quirk et al. 1985: 1323; Payne and Huddleston 2002: 435). However, this construction did not occur until the thirteenth century in English (Fischer 1992: 215), and has a somewhat special status, in that the indefinite article in this construction, like in its Dutch counterpart, is historically presumably a reinterpreted flexional morpheme (van der Horst and Van de Velde 2003). An additional problem with regard to criterion (v) is that we need to establish indepedently which elements are modifiers. An obvious criterion may be: an adnominal dependent that does not conform to at least one of the criteria (I-IV) is not a determinative, but a modifier.

These five criteria should be interpreted strictly: (I) does not exclude that languages without articles have a determiner position. Nor does it imply that the articles are the only determinatives in a language that has them. (II) does not exclude that several determiners co-occur in one NP. (III) does not say that determiners are necessarily obligatory. (IV) does not exclude other adnominal dependents (modifiers) to be barred from the predicate position, albeit for totally different reasons. And (v) does not say that far left position is decisive for attributing determiner status.

Other properties the literature associated with determiners are less amenable to serve as reliable diagnostics. Consider for instance the alleged nongradability of determiners. True, morphological grading is rare or nonexistent with determiners, but scalar focus particles like almost, which are closely related to grading adverbs are readily found in front of determinatives: almost every book $(\mathrm{G})$; quite some time $(\mathrm{G})$. Another criterion mentioned in Pullum and Huddleston (2002: 539) to distinguish determinatives from modifiers is the partitive construction, but again, this is neither a necessary nor a sufficient characteristic of determinatives (see Bolinger 1972: 136 for examples with modifiers followed by of ).

If interpreted strictly, these criteria ( $\mathrm{I}-\mathrm{V})$ overcome the objections Denison (2006: 283) and Van Eynde (2006: 156-157) (among others) raise 
against the traditional criteria. With these five criteria, we are now in a position to track the history of the determiner in Dutch.

\section{The history of the determiner in Dutch}

\subsection{No determiner in Proto-Germanic}

First, it is to be established when in its history Dutch has acquired a determiner slot in the NP. By the criteria (I)-(v), it can be deduced that Proto-Germanic, the predecessor of Old Dutch, did not have a determiner position, as can be gleaned from cognate languages, like Gothic, Old English etc. To begin with, the article had not yet developed (Lehmann 1994: 28). Second, the possessive was not yet a determinative, since it could function as a predicate: 6

(11) Old English

se ðe ne gimð ðara ðe his beoð

he RP not cares that RP his are

'he that does not care for what is his'

(Mitchell 1985: 122)

Third, the demonstrative could still occur to the right of the possessive, suggesting it was not a determiner either.

(12) Old English

his ba afestan tungan

his that pious tongue

'that pious tongue of his'

(Mitchell 1985: 51)

This is corroborated by the observation that ordinary adjectives could still precede the demonstrative and the possessive pronoun, suggesting that neither of them are determinatives:

(13) Old English

on wlancan pam wicge

on proud that horse

'on that proud horse'

(Mitchell 1985: 70)

(14) Old High German

lieba sin uuirten

kind his landlady

'his kind landlady'

(Schrodt 2004: 30) 


\subsection{The emergence of a determiner in Old Dutch}

Old Dutch, as well as contemporaneous Old English, developed an article, first the definite article, and later, around 1000AD, an indefinite one. By criterion (I), this is positive evidence of the existence of a determiner slot in the NP. This concurs with Lyons's (1999: 323) statement that:

"The diachronic emergence of definite articles (...) represents the appearance of the category of definiteness in languages, and amounts to a change in syntactic structure: the creation of a DP projection."

The question then is what other elements belonged to that slot in Old Dutch.

Of the pronouns, the demonstrative is the most likely candidate for determiner status. It is the source the article is derived from, and it stopped occurring after the possessive in Old Dutch ${ }^{7}$, a position it could well occupy in early Old English, as was illustrated in (12). The demonstrative after an ordinary adjective, as in (13), was already rare in Old English, as Mitchell (1985: 70) notes. The demonstrative pronoun and the nascent article are arguably the only determinatives in Old Dutch. Possessives were not, as they still occurred as predicates, as e.g., in:

(15) Old Dutch, 9th/10th century

Min ist Galaad

my is $\mathrm{G}$.

'G. is mine'

(De Grauwe 1982: 444)

As the possessive was not a determinative, it did not entail definiteness, and it could well be preceded by a demonstrative or (as soon as the indefinite article developed) an indefinite article:

(16) Old Dutch, 11th century

thaz min wighus

That my citadel

'that citadel of mine'

(van der Horst 2008: 313)

(17) Middle Dutch, 13th/14th century

een sijn oude vrient

a his old friend

'an old friend of his'

(Duinhoven 1988: 188) 
Furthermore, it could still be found to the right of modifiers:

(18) Old Dutch, 11th century

zuene thine spune

two your breasts

'your two breasts'

(van der Horst 2008: 313)

(19) Old Dutch, 11th century

ande andera sina dona

and other his gifts

'and his other gifts'

(van der Horst 2008: 313)

Quantifiers and numerals were not determinatives either. They could still function as a predicate. I have not found any example of such a construction in Old Dutch texts, but since it is attested in Old English and Old High German as well as in Middle Dutch, as in (20), it can be safely assumed that its absence in Old Dutch is coincidental. ${ }^{8}$ Indeed, numerals were permitted in predicate position until the 19th century in Dutch (van der Horst 2008: 1705).

(20) Middle Dutch, 15th century

die chierheden der gehoorsamheit sijn seven

the beauties of obedience are seven

'there are seven beauties of obedience'

(Duinhoven 1988: 81)

\subsection{Consolidation of the determiner slot}

The determiner slot, an innovation of Old Dutch, was consolidated in Middle Dutch. A first instance of this consolidation is the more predictable and stringent distribution of the article. In Middle Dutch, the article is definitely more common than in Old Dutch, but there is still some variation, compare e.g., the "minimal pair" in (21)-(22). This variation gradually diminishes over the centuries.

(21) Middle Dutch, 13th/14th century

in lant van Iudeen

in country of $\mathbf{J}$.

'in the country J.'

(van der Horst 2008: 391) 
(22) Middle Dutch, 13th/14th century

in tlant van Judea
in the.country of J.
'in the country J.'
(MNW, s.v. niewer)

A second instance of the elaboration of the determiner goes under the heading of extension (Harris and Campbell 1995) or intraference (Croft 2000: 148-156). Determiner status, originally exclusively associated with the article, is extended to other words it shares semantic or pragmatic traits with. In other words: more and more lexemes become determinatives. The accretion of the determiner slot can then be considered as a syntactic change that involves lexical diffusion (Harris and Campbell 1995: 106-107).

\section{A diachronic account of the growing number of determinatives}

In this section, the growing number of determinatives in Dutch is examined in detail. It will be argued that he following adnominal elements undergo a shift from modifier to determinative: (a) possessive pronouns, (b) the demonstrative manner pronoun, (c) demonstrative manner adjectives, and (d) anaphoric adjectives. Of these, only the possessive pronouns occasionally feature in diachronic accounts of NP structure. The determiner capacities of the other ones are less known. Additionally, a few recent (20th century) incipient shifts from modifier to determinative will be looked at.

Arguments for such a shift will be derived from the increasing conformity to the characteristics of typical determiners. Of the criteria mentioned under (6)-(10), criteria (II), (IV) and (v) will be used to check whether a certain element has become a determinative. Additionally, the change will be traced with quantitatively analyzed corpus material, which makes clear that the shift to the determiner category is both a gradual and a long-term process.

\subsection{Possessive pronouns}

As was mentioned above, the possessive pronoun was not a determinative yet in Old Dutch. In Middle Dutch, it begins to acquire determiner properties: (i) it gradually becomes mutually exclusive with the article and the demonstrative, (ii) it stops functioning as a predicate and (iii) it stops occurring to the right of a modifier. The first two properties have been mentioned before in the literature (Duinhoven 1976). The third observation is not taken into account by Duinhoven, but is in accordance with the other two. 
4.1.1. Possessive pronouns in combination with other determinatives. In Middle Dutch, like in Old Dutch, possessives can still be preceded by a demonstrative or an article, as is exemplified in the early Middle Dutch example in (23), although the construction is on the decline. Duinhoven (1972: 345, 1988: 189) thinks that it became extinct by the end of the Middle Dutch period. This is not entirely accurate: Van der Horst (2008) mentions Modern Dutch examples, like (24).

(23) Middle Dutch, 13th century

Die sine voghele aten worme ende serpente vtermaten those his birds ate worms and serpents excessively 'Those birds of his ate a lot of worms and serpents' (van der Horst 2008: 351)

(24) Modern Dutch, 19th century deze zijne aanmerking this his comment

'this comment of his' (van der Horst 2008: 1962)

The extinction of the construction with both a demonstrative and a possessive in present-day language suggests that something has happened to the syntactic behavior of the possessive. The complementary distribution suggests that it has shifted from modifier to determinative.

4.1.2. The possessive pronoun as a predicate. At the start of the Middle Dutch period, the possessive could be frequently encountered in predicate function. An early Middle Dutch example is given in (25).

(25) Middle Dutch, 12th century

Al ware al de weerelt dijn

even.if were all the world your

'Even if the whole world were yours'

(van der Horst 2008: 375)

This construction survives through Middle Dutch, and sporadically pops up (as an obsolete construction) until the 19th century (Duinhoven 1976: 410). The construction is currently not grammatical anymore, suggesting that the status of the possessive pronoun has changed. The transition of the possessive pronoun from modifier to determinative thus seems not to be completed until quite recently, in the 20th century.

4.1.3. The possessive pronoun after a modifier. As was mentioned in Section 3.2 (see Examples [18] and [19]) the possessive pronoun could be preceded by an adjective or a numeral in Old Dutch, and this is still pos- 
sible to some extent in Middle Dutch. A late attestation is the example under (26).

(26) Middle Dutch, 16th century

Waerdighe onse zeer lieve ende beminde burgemeesteren worhty our very kind and beloved mayors

'Our worthy, very kind and dear mayors' (van der Horst 2008: 1035)

In Modern Dutch, the construction eventually disappears. In present-day Dutch, the word order in (27)-(28) is outright ungrammatical.

(27) Middle Dutch, 15th century

die andre sine broeders

the other his brothers

'the other brothers of his'

(van der Horst 2008: 763)

(28) Middle Dutch, 15th century

van drien zijnen ruddaren

of three his knights

'of three of his knights'

(van der Horst 2008: 763)

4.1.4. Quantitative evidence. The possessive pronouns seem to function invariably as determiners in early Modern Dutch. Still, some vestiges of adjunct use remain, as can be demonstrated by the corpus inquiry summarized in Table 1 and the associated bar chart. ${ }^{9}$ The results have been analyzed statistically. ${ }^{10}$

Table 1. Possessive pronoun ons

\begin{tabular}{|c|c|c|c|}
\hline \multirow{2}{*}{$\begin{array}{l}\text { Age } \\
\text { Frequency } \\
\text { Raw percentage }\end{array}$} & \multicolumn{3}{|c|}{ Construction } \\
\hline & Modifier & Determiner & Tota \\
\hline 16th century & $\begin{array}{l}6 \\
8.57 \%\end{array}$ & $\begin{array}{l}64 \\
91.43 \%\end{array}$ & 70 \\
\hline 17 th century & $\begin{array}{l}11 \\
8.59 \%\end{array}$ & $\begin{array}{l}117 \\
91.41 \%\end{array}$ & 128 \\
\hline 18th century & $\begin{array}{l}1 \\
1.52 \%\end{array}$ & $\begin{array}{l}65 \\
98.48 \%\end{array}$ & 66 \\
\hline 19th century & $\begin{array}{l}0 \\
0.00 \%\end{array}$ & $\begin{array}{c}83 \\
100.00 \%\end{array}$ & 83 \\
\hline 20th century & $\begin{array}{l}0 \\
0.00 \%\end{array}$ & $\begin{array}{l}191 \\
100.00 \%\end{array}$ & 190 \\
\hline Total & 18 & 520 & 538 \\
\hline
\end{tabular}


Statistics

Fisher's Exact Test: Table Probability $(\mathrm{P})<0.0001 ; \operatorname{Pr} \leq \mathrm{P}<0.0001$

Gamma: 0.7678; ASE: 0.0557

In a bar chart, this looks as follows:

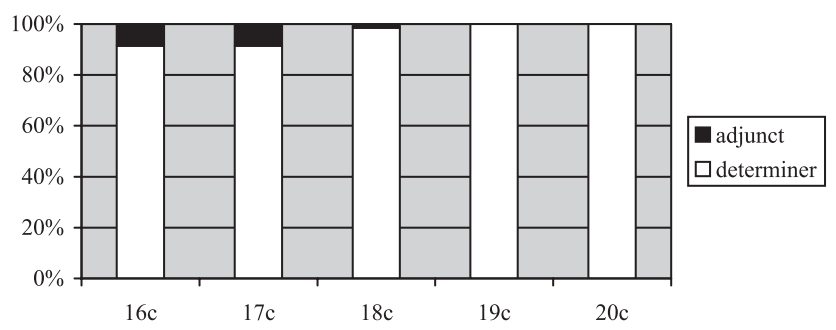

Figure 1. Bar chart of possessive pronoun (ons)

\subsection{The demonstrative manner pronoun}

Such is hard to classify as a part of speech. It stands midway between a pronoun and a manner adverb or adjective. Its difficult classification may be partly due to its slippery semantics. In Middle Dutch, sulc 'such' could convey quantificational meaning or nonspecificity (MNW, s.v. sulc; see also Duinhoven 1988: 127), among other things. Tracing the syntactic history of Dutch zulk 'such' is not an easy task. Yet, there are a good number of arguments to assume that it too has made a shift from modifier to determinative.

Like today, zulk could be used in front of a noun in Old Dutch:

(29) Old Dutch, 11th century

in sulichemo bedde

in such bed

'in such a bed'

(van der Horst 2008: 167)

A rash conclusion would be that sulichemo functions as a determiner, by the absence of an article. The feeble status of the article in Old Dutch, however, does not lend support to such a conclusion. It is more likely that sulichemo is a modifier rather than a determinative. For one thing, it could function as a predicate: 
(30) Old Dutch, 11th century

Sulich is $\mathrm{min}$ drut

such is my beloved

'Such is my beloved'

(van der Horst 2008: 167)

During the Middle Dutch period, zulk becomes a determinative, as will become clear in the following subsections.

4.2.1. The demonstrative manner pronoun in combination with other determinatives. Although not very frequently, zulk can be combined with an article or a demonstrative in Middle Dutch:

(31) Middle Dutch, 15th century

een sulc gheschal

a such blare

'such a blare'

(MNW, s.v. tamboere)

(32) Middle Dutch, 15th century

die sulke riddere

that such knight

'the knight of that sort'

(MNW, s.v. begeringe)

Both constructions are ruled out in present-day Dutch.

4.2.2. The demonstrative manner pronoun as a predicate. The Old Dutch construction in (30), with zulk functioning as a predicate is also encountered in Middle Dutch:

(33) Middle Dutch, 13th century

Si mochten sulc sijn

they might such be

'They might be/may have been such'

(Duinhoven 1988: 129)

This construction is no longer grammatical in present-day Dutch. Again, the extinction process has taken several centuries: though not very common, the construction can be encountered in the (Modern Dutch) WNT citation material. The construction dies out in the 16th century: the most recent attestations the WNT mentions s.v. zulk, date from the early 17 th century: ${ }^{11}$ 
(34) Modern Dutch, 17th century

Gelijck ' $t$ oneedel bloedt Sulck $u$ hantering is like the ignoble blood such your wielding is 'Your wielding is like the ignoble blood' (WNT s.v. zulk)

4.2.3. The demonstrative manner pronoun after a modifier. In Middle Dutch, zulk is occasionally found after adnominal modifiers that nowadays have to follow it:

(35) Middle Dutch, 15th century

ende noch andere sulke sendinge

and still other such gifts 'and such other gifts'

(MNW, s.v. sendinge)

Though virtually excluded in Present-day Standard Dutch, this use of zulk is still possible in the 19th century:

(36) Modern Dutch, 19th century

of andere zulke beuzelaryen

or other such trivialities

'or such other trivialities'

(WNT, s.v. vallen)

Intriguingly, zulk can occur after numerals, even today:

(37) Present-day Dutch, 20th century

drie zulke opwaartse golven

three such upward waves

'three such upward waves'

(INL38)

But this may be due to the fact that numerals are themselves involved in a similar change: there are indications that numerals have recently become determinatives. For one thing, they have stopped occurring as a predicate during the 19th century (van der Horst 2008).

4.2.4. Quantitative evidence. The gradualness of the shift from adjective to determiner of $z u l k$ can be illustrated by quantitative corpus inquiry in the citation material of $\mathrm{WNT}^{12}$ : Table 2 shows the proportion of instances of zulk preceded by a demonstrative over instances of zulk followed by a determiner, or behaving as a determiner itself: ${ }^{13,14}$ 
Table 2. Demonstrative manner pronoun zulk

\begin{tabular}{lccc}
\hline \multicolumn{1}{c}{ Age } & \multicolumn{3}{c}{ Construction } \\
\cline { 3 - 4 } $\begin{array}{l}\text { Frequency } \\
\text { Raw percentage }\end{array}$ & Modifier & Determiner & Total \\
\hline 16th century & 7 & 39 & 46 \\
17th century & $15.22 \%$ & $84.78 \%$ & \\
& 8 & 88 & 96 \\
18th century & $8.33 \%$ & $91.67 \%$ & 84 \\
19th century & 7 & 77 & \\
& $8.33 \%$ & 145 & 146 \\
20th century & 1 & $99.32 \%$ & 58 \\
& $0.68 \%$ & 58 & \\
Total & 0 & $100.00 \%$ & 430 \\
\hline
\end{tabular}

Statistics

Fisher's Exact Test: Table Probability $(\mathrm{P})<0.0001 ; \operatorname{Pr} \leq \mathrm{P}<0.0001$

Gamma: 0.6351; ASE: 0.0833

This can be visualized as follows:

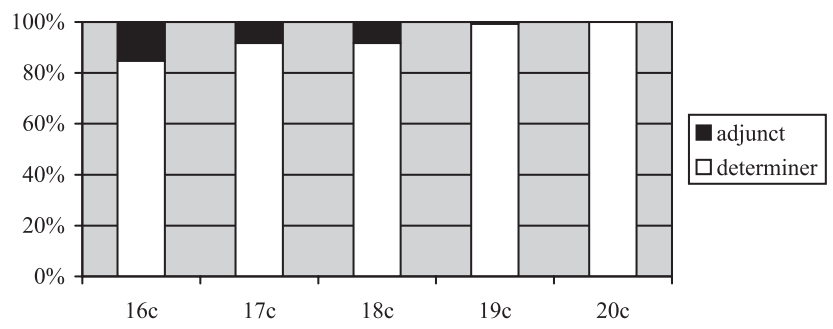

Figure 2. Bar chart of demonstrative manner pronoun (zulk)

Additional support for the idea that zulk has turncoated can be derived from its combination with negation. In Dutch, there is a difference between geen en niet: roughly stated, the former is used as a determiner in the NP, the latter in all other cases. The difference is comparable to English no versus not. If zulk is becoming a determinative, it is to be expected that it be increasingly found in combination with niet 'not', rather than with geen 'no': niet combines with determiners, and geen with adjectives. This is indeed what we find. 
Table 3. Zulk in combination with negation

\begin{tabular}{|c|c|c|c|}
\hline Age & & onstruction & \\
\hline $\begin{array}{l}\text { Frequency } \\
\text { Raw percentage }\end{array}$ & $\begin{array}{l}\text { geen zulk } \\
\text { (modifier) }\end{array}$ & $\begin{array}{l}\text { niet zulk } \\
\text { (determiner) }\end{array}$ & Tota \\
\hline 16th century & $\begin{array}{c}6 \\
50.00 \%\end{array}$ & $\begin{array}{c}6 \\
50.00 \%\end{array}$ & 12 \\
\hline 17th century & $\begin{array}{c}6 \\
40.00 \%\end{array}$ & $\begin{array}{l}9 \\
60.00 \%\end{array}$ & 15 \\
\hline 18 th century & $\begin{array}{l}3 \\
60.00 \%\end{array}$ & $\begin{array}{c}2 \\
40.00 \%\end{array}$ & 5 \\
\hline 19th century & $\begin{array}{l}10 \\
20.00 \%\end{array}$ & $\begin{array}{l}40 \\
80.00 \%\end{array}$ & 50 \\
\hline 20th century & $\begin{array}{l}0 \\
0.00 \%\end{array}$ & $\begin{array}{c}23 \\
100.00 \%\end{array}$ & 23 \\
\hline Total & 25 & 80 & 105 \\
\hline
\end{tabular}

Statistics

Fisher's Exact Test: Table Probability $(\mathrm{P})<0.0001 ; \operatorname{Pr} \leq \mathrm{P}=2.797 \mathrm{E}-04$ Gamma: 0.6662; ASE: 0.0968

In a bar chart, this looks as follows:

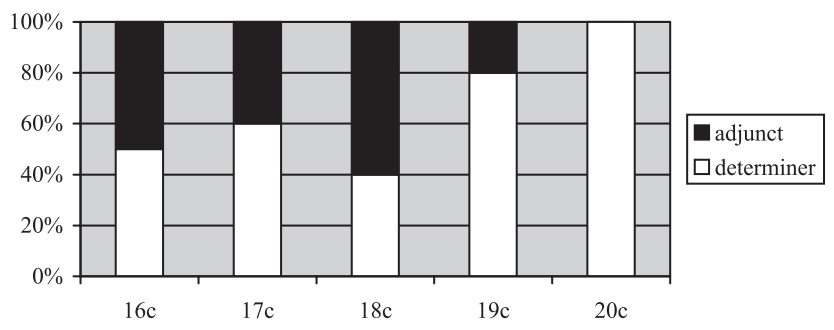

Figure 3. Bar chart of zulk in combination with negation

With the exception of the 18th century, the use of the negation niet shows a steady increase in the determiner use of zulk. The results of the statistical tests show that the deviance in the 18th century is not structural, but rather due to the low number of attestations in this period, as the gamma value shows a strong positive correlation.

\subsection{Demonstrative manner adjectives}

Semantically related to the demonstrative manner pronoun are what I would like to call "(demonstrative) manner adjectives": dergelijke, dusda- 
nige, zodanige, zulkdanige, which all can be translated as 'that kind of', 'suchlike' or 'similar'. Just like the demonstrative manner pronoun zulk, they too are making their way to become determinatives, although they seem to loiter somewhat, as they still exhibit plenty of modifier characteristics in 20th century Dutch.

4.3.1. The demonstrative manner adjective in combination with other determinatives. The adjectives at issue vary with regard to their occurrence in combination with an article or another determinative. Unlike the previously discussed zulk, the adjectives dergelijke, dusdanige, zodanige en zulkdanige can all be preceded by an article in present-day Dutch:

(38) Present-day Dutch, 20th century

een dergelijke oplossing

a suchlike solution

(WNT, s.v. redengevend)

The construction in (38) is not possible with a definite article. Diachronically, the definite article is thus more readily dropped than the indefinite, or, to put it more accurately: when the demonstrative manner adjective becomes a determinative, it is definite. Just like other definite NPs, it cannot appear in existential constructions: the indefinite article in (39) cannot be dropped.

(39) Present-day Dutch

Er is een dergelijke hype dat (...)

there is a suchlike hype that

'There is such a hype that (...)'

(G)

(40) *Er is dergelijke hype dat (...)

The demonstrative manner adjectives lag behind the demonstrative manner pronoun zulk in the process of becoming determinative: not only do they frequently occur after indefinite articles as was just demonstrated in (39), they are also sporadically found after a definite determiner in 20th century Dutch:

(41) Present-day Dutch, 20th century

in alle dergelijke gevallen

in all suchlike cases

'in all such cases'

(WNT, s.v. relativistisch)

4.3.2. The demonstrative manner adjective as a predicate. Even though Duinhoven (1976: 427) considers the construction ungrammatical, 
historical data show that demonstrative manner adjectives do occur as a predicate, even in the 20th century:

(42) Present-day Dutch, 20th century

Deze bevestiging is dusdanig, dat (..)

this fixing is suchlike, that

'This fixing is such that (...)'

(WNT, s.v. hoofd [aanv.])

However, not all demonstrative manner adjectives display this possibility to the same extent. In about 700 instances of dergelijk drawn from the WNT, the construction is totally absent.

4.3.3. The demonstrative manner adjective after modifiers. In early Modern Dutch, demonstrative manner adjectives can occur both after and in front of adjectives, as is shown in the 17 th century "minimal pair" in (43)-(44).

(43) Modern Dutch, 17th century

diergelijcke ander hout

suchlike other wood

'such other wood'

(WNT, s.v. raspen)

(44) Modern Dutch, 17th century

andere dierghelijcke houten

other suchlike woods

'other similar kinds of wood'

(WNT, s.v. raspen)

At present, the construction is only possible with indefinite NPs, where the demonstrative manner adjectives have not (yet) acquired determiner characteristics. The last demonstrative manner adjective after a modifier in a definite NP dates from the 19th century:

(45) Modern Dutch, 19th century

in alle andere dergelyke omstandigheden

In all other suchlike circumstances

'in all other similar circumstances'

(WNT, s.v. tucht)

In indefinite NPs the demonstrative manner adjective can also follow a numeral. In (46), a 20th century example is given.

(46) Present-day Dutch, 20th century

Een samenstel van vijf dergelijke netten

a set of five suchlike nets 
'A set of five such nets'

(WNT, s.v. reep [I])

4.3.4. Quantitative evidence. The shift from modifier to determinative can be quantitatively traced. ${ }^{15}$ As the shift manifests itself only in definite NPs, indefinite NPs have been ignored. With the 20th century deviating somewhat, the proportion of adjunct use over determiner use of demonstrative manner adjectives decreases over the centuries. ${ }^{16}$

Table 4. Demonstative MANNER ADJECTIVE: dergelijke, dusdanig, zodanig, zulkdanig

\begin{tabular}{|c|c|c|c|}
\hline \multirow{2}{*}{$\begin{array}{l}\text { Age } \\
\text { Frequency } \\
\text { Raw percentage }\end{array}$} & \multicolumn{3}{|c|}{ Construction } \\
\hline & Modifier & Determiner & Total \\
\hline 16th century & $\begin{array}{c}8 \\
36.36 \%\end{array}$ & $\begin{array}{l}14 \\
63.64 \%\end{array}$ & 22 \\
\hline 17 th century & $\begin{array}{l}10 \\
12.50 \%\end{array}$ & $\begin{array}{l}70 \\
87.50 \%\end{array}$ & 80 \\
\hline 18th century & $\begin{array}{c}8 \\
11.43 \%\end{array}$ & $\begin{array}{l}62 \\
88.57 \%\end{array}$ & 70 \\
\hline 19th century & $\begin{array}{l}2 \\
4.44 \%\end{array}$ & $\begin{array}{l}43 \\
95.56 \%\end{array}$ & 45 \\
\hline 20th century & $\begin{array}{l}4 \\
8.00 \%\end{array}$ & $\begin{array}{l}46 \\
92.00 \%\end{array}$ & 50 \\
\hline Total & 32 & 236 & 268 \\
\hline
\end{tabular}

Statistics

Chi-Square: DF 4; Value $=15.6140 ; \mathrm{P}=0.0036$

Gamma: 0.3739; ASE: 0.1321

The corresponding bar chart looks as follows:

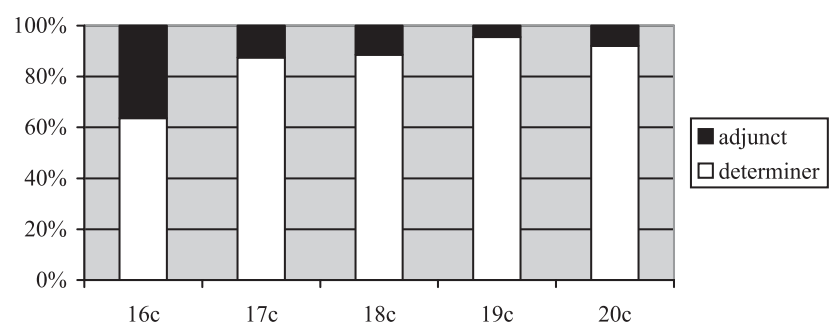

Figure 4. Bar chart of demonstrative manner adjectives (dergelijke, dusdanig, zodanig, zulkdanig) 


\subsection{Anaphoric adjectives}

The term "anaphoric adjectives" is here used for adjectives like voornoemd, voormeld, etc. ('aforementioned'). Like the demonstrative manner pronoun and adjectives discussed in the previous sections, they seem to be increasingly used as determiners as well.

4.4.1. Anaphoric adjectives in combination with other determinatives. Anaphoric adjectives still occur with the demonstrative and the article, as is illustrated in (47). In a theoretical model that does not allow gradualness, this would be an argument to deny them determiner status. They would be postdeterminers at best.

(47) Present-day Dutch, 20th century

De voornoemde bouwstoffen

the aforementioned building.materials

'The aforementioned building materials'

(WNT, s.v. overjaren)

In Section 4.4.4, however, it is shown that the article in such constructions is omitted to an increasing extent. This is not due to the capricious nature of the article, as is sometimes assumed, but rather an indication of a change in the syntactic status of the adjective.

4.4.2. The anaphoric adjective as a predicate. In early Middle Dutch, anaphoric adjectives occur in predicate position, as is illustrated in (48), but by the end of the Middle Dutch period, the construction seems extinct. The last occurrences I have come across in the citation material of the MNW and the WNT date back to the 14th century.

(48) Middle Dutch, 14th century

de penninghe, de vorghenomet sijn

The pennies that aforementioned are

'the aforementioned pennies'

(MNW, s.v. vorenoemen)

4.4.3. The anaphoric adjective after modifiers. In early Modern Dutch (16th and 17th century), anaphoric adjectives are occasionally found after a modifier, as in (49), but it seems that these are the last instances of the construction. I have not found any 18 th century or later examples.

(49) Middle Dutch, 16th century

$\begin{array}{lllll}\text { wt alle die fraye } & \text { voornoemde } & \text { auteuren } \\ \text { out all those beautiful aforementioned } & \text { authors }\end{array}$


'in [the work of] all those aforementioned beautiful authors'

(WNT, s.v. verduft)

After numerals, the anaphoric adjective survives longer. Example (50) dates from the 19th century. Again, this may be due to a shift in the syntactic behavior of numerals (see above).

(50) Modern Dutch, 19th century

de twee voornoemde bestanddeelen onzer voeding

the two aforementioned ingredients of.our food

'the aforementioned two ingredients of our food'

(WNT, s.v. giftig [aanv.])

4.4.4. Quantitative evidence. Judging by their co-occurrence with demonstratives and articles (Section 4.4.1), the anaphoric adjectives are not determinatives. The observations in Section 4.4.2 and Section 4.4.3, however, suggest that the condition of the anaphoric adjectives has somehow changed since Middle Dutch. This is corroborated by corpus inquiry, revealing that co-occurrence with other determinatives is not excluded in present-day Dutch, but has drastically diminished. Again, this is a gradual process.

Table 5. Anaphoric ADJECTIVE voornoemd

\begin{tabular}{|c|c|c|c|}
\hline \multirow{2}{*}{$\begin{array}{l}\text { Age } \\
\text { Frequency } \\
\text { Raw percentage }\end{array}$} & \multicolumn{3}{|c|}{ Construction } \\
\hline & Modifier & Determiner & Tota \\
\hline 15 th century & $\begin{array}{c}15 \\
100.00 \%\end{array}$ & $\begin{array}{l}0 \\
0.00 \%\end{array}$ & 15 \\
\hline 16th century & $\begin{array}{l}569 \\
98.96 \%\end{array}$ & $\begin{array}{l}6 \\
1.04 \%\end{array}$ & 575 \\
\hline 17 th century & $\begin{array}{l}645 \\
95.27 \%\end{array}$ & $\begin{array}{l}32 \\
4.73 \%\end{array}$ & 677 \\
\hline 18 th century & $\begin{array}{l}238 \\
88.81 \%\end{array}$ & $\begin{array}{l}30 \\
11.19 \%\end{array}$ & 268 \\
\hline 19th century & $\begin{array}{l}50 \\
66.67 \%\end{array}$ & $\begin{array}{l}25 \\
33.33 \%\end{array}$ & 75 \\
\hline 20th century & $\begin{array}{c}5 \\
31.25 \%\end{array}$ & $\begin{array}{l}11 \\
68.75 \%\end{array}$ & 16 \\
\hline Total & 1522 & 104 & 1626 \\
\hline
\end{tabular}

Statistics

Fisher's Exact Test: Table Probability $(\mathrm{P})<0.0001 ; \operatorname{Pr} \leq \mathrm{P}<0.0001$

Gamma: 0.7332; ASE: 0.0427 
In a bar chart:

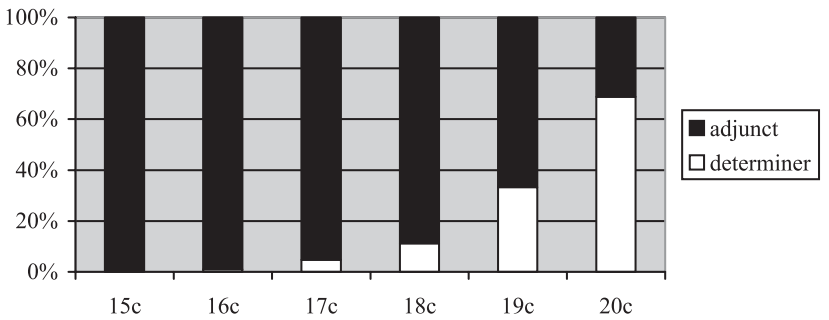

Figure 5. Bar chart of anaphoric adjective (voornoemd)

\subsection{Incipient determiner shifts}

As was shown in the previous sections, various modifiers have become determinatives in Dutch. One could say that the determiner slot has recruited more and more adjectives and pronouns. The transition from modifier to determinative is a gradual process. For possessives, demonstrative manner pronouns and demonstrative manner adjectives, this process has advanced to next to completion. Anaphoric adjectives are also widely used as determiners, but it would go too far to say that they have definitively left the adjunct slot.

In this section, some adnominal dependents are discussed that have only just begun to make the shift: the instances of determiner use are outnumbered by the adjunct use to an extent that would make these budding determinatives hardly visible in a bar chart. Some grammars may insist on them being occasional "errors", but in view of the fact that other adnominal elements have been observed to cross the adjunct-determiner boundary, however, the occasional determiner use of these adjectives is arguably not coincidental.

The first group of incipient determinatives is formed by the adjectives of comparison: zelfde 'same' and ander 'other'. Breban (2003) and Breban and Davidse (2003) show that in English, these adjectives differ from others in that they have grammaticalized into postdeterminers. I think postdeterminers can best be considered as an intermediary stage between modifier and determinative both synchronically and diachronically: they do no longer occur to the right of modifiers (criterion v), but they do not (yet) stand in complementary distribution with other determinatives (criterion II). This differential behavior with regard to the various criteria was also displayed by the other new determinatives: in the 17 th century, 
possessive pronouns stop occurring to the right of modifier adjectives, while they still combine with other determiners until at least the 19th century.

In Dutch, the postdeterminer use of the adjectives of comparison has very recently been pushed a little further in that it occasionally takes the position of the determiner. The examples under (51)-(52) are ungrammatical for most speakers, but they do occur:

(51) Present-day Dutch

hebben jullie gisteren of misschien andere keer blair
have you yesterday or maybe other time blair
witch project 2 gezien?
witch project 2 seen

'Did you see Blair Witch Project 2 yesterday or maybe some other time?'

(G)

(52) Present-day Dutch

Over 10 jaar staat er weer iemand met ander in 10 year stands there again someone with other verhaal, die dan beweert de juiste oplossing story who then claims the right solution te hebben.

to have

'in 10 years there will again be someone with yet another story, who then claims to have the right solution.'

(G)

(53) Present-day Dutch

Madrid staat inmiddels tweede met zelfde aantal Madrid stands meanwhile second with same number punten als Valencia points as Valencia

'Madrid meanwhile ranks second with the same number of points as Valencia'

(G)

In (51), (52) and (53), most speakers would still prefer a definite or indefinite article, or some other determiner in front of ander of zelfde.

A second group of incipient determiners are those that may be grouped together as epistemic adjectives, which express the speaker's assessment of the likelihood of occurrence of the noun: verwacht 'expected', te verwachten 'to be expected', gebruikelijk 'usual', etc. Halliday (1994: 183) considers them as postdeictics (his term for postdeterminers), and indeed, 
they cannot occupy the determiner position on their own. In Dutch, however, some of them can occasionally be found without a "proper" determinative, as illustrated in (54)-(57). Again, it remains to be seen whether these examples are not merely due to occasional editorials slips, but in the light of the aforementioned modifier-to-determinative shifts, they are at least suspicious.

(54) Present-day Dutch, 20th century

In Zuid-Afrika stevent 't ANC af op

In South-Africa steers the ANC off on

verwachte overwinning.

expected victory

'In South Africa the ANC is heading for an expected victory' (INL38)

(55) Present-day Dutch

Dit is verwachte gevolg van jaren gesjoemel met

this is expected consequence of years cheating with

de boekhouding

the accounting

'This is the expected consequence of years of tampering with the books'

(G)

(56) Present-day Dutch

Investeer in teambuilding in relatie tot te verwachten invest in team.building in relation to to expect eindproduct

end-product

'Invest in team building in relation to the expected end product'

(G)

(57) Present-day Dutch

Eerst wordt de hond op gebruikelijke manier onder

first is the dog in usual manner under

narcose gebracht

anaesthesia brought

'First, the dog is anaesthesized in the usual way'

(G)

The idea that there is more going on in (54)-(57) than mere editorial inadvertence, is strengthened by examples like (58) and (59). Here the epistemic adjectives gebruikelijk 'usual' and nodig 'necessary' occur in a plural NP, which makes it difficult to decide whether they really function as determiners here. However, the adjectives stand in front of a numeral, an 
atypical position for ordinary adjectives. Moreover, the construction is ungrammatical in English.

(58) Present-day Dutch

Kim's moeder (...) begroette me met gebruikelijke

Kim's mother greeted me with usual

drie kussen op de wang.

three kisses on the cheek

'Kim's mother (...) greeted me with the usual three kisses on the cheek'

(G)

(59) Present-day Dutch

Op het Fort van Koningshooikt was André Vromans

on the fortress of Koningshooikt was A. V.

niet aan nodige twee reekszeges geraakt

not on needed two series.victories obtained

'On the fortress of Koningshooikt, André Vromans did not obtain the two series victories needed.'

(G)

Besides the adjectives of comparison and the epistemic adjectives, there may be other adjectives that can occasionally be used in determiner function as well in Present-day Dutch. Some are related to the domain of locality, like tegengesteld 'opposite', which Davidse et al. (2008) observe to behave as a postdeterminer in some contexts in English. Their semantics make them suitable to function as deictic elements in the NP, and in Dutch, they are - not unexpectedly - occasionally used as determiners, as exemplified in (60) and (61).

(60) Present-day Dutch, 20th century

in tegengestelde richting

in opposite direction

'in the opposite direction'

(WNT, s.v. antipode [supp.])

(61) Modern Dutch, 19th century waar op hetzelfde oogenblik de moleculen tegengestelde where on the.same moment the molecules opposite beweging hebben

movement have

'where at the same moment, the molecules move in opposite directions'

(WNT, s.v. knoop) 


\section{Theoretical embedding}

\subsection{Leftward movement of adjectives}

The change from modifier to determinative is not restricted to Dutch. In English too, modifiers seem to become determinatives over time. Support for this idea comes from the observation that adjectives undergo leftward movement (Adamson 2000), to become postdeterminers (Breban 2003, Breban and Davidse 2003). This leftward movement can be linked to criterion (v) in (10): the transition from modifier to determinative entails a preference for a position to the left of all modifiers. But this is only part of the story. The other criteria mentioned in (6)-(9) are equally relevant. Leftward movement goes hand in hand with e.g., an aversion to predicate function. Indeed, postdeterminers like same, other and usual sound awkward as (characterizing) ${ }^{17}$ predicates, as illustrated in (63). Note that usual did occur in predicate position in former stages of English, as illustrated in (64). ${ }^{18}$

(62) All he wants is the usual three wishes

(G)

(63) ?? The three wishes are usual

(64) Why truth on't is, these early Sallies are not usual to me.

(17th century, OED, s.v. usual)

Contrary to what is assumed by Breban and Davidse (2003), or by Halliday (1994), I do not think that the abstract NP template as it is represented in (2) should be enriched by a separate postdeterminer slot. The "postdeterminer" is only a useful label for a transitional stage in the diachronic modifier-to-determinative transformation, and should not be attributed a structural position in the NP. Seen from another angle, the possessive pronoun once was a postdeterminer too.

In this view, postdeterminer slotfillers can be expected to proceed to full-fledged determinatives: if the Dutch development as described in the previous sections can indeed be extended to English, it would be predicted that it is only a matter of time before same, other or usual are mutually exclusive with articles. ${ }^{19}$

Dutch may then be ahead of English in the process of recruiting new determinatives. The Dutch demonstrative manner pronoun zulk e.g., arguably has developed further than its English counterpart such in this respect. Only the latter can still be used as a predicate and can still occur after quantifiers like some, all and every. The same might be the case with the incipient determiners in Section 4.5. 


\subsection{Grammaticalization, deictification and subjectification}

The modifier-to-determiner transition can be looked at from different angles. If the process is approached from the point of view of the individual lexemes or lexeme classes (possessives, demonstrative manner pronouns, anaphoric adjectives etc.), each shift from modifier to determinative can be seen as an isolated instance of grammaticalization (Hopper and Traugott 2003). But in order to fully grasp what is going on in Dutch (and English) NPs, a wider scope is needed: instead of taking the perspective of the individual lexemes, the whole process must be looked at from the perspective of the abstract determiner slot itself. All separate instances of grammaticalization of the individual lexemes are in fact part of a larger process, viz. the emergence of the determiner slot in Old Dutch and the subsequent growth of its membership figure.

Such an approach is not unrelated to a recent trend in grammaticalization theory that focuses on its constructional aspect. Although the idea that the emergence of abstract constructions, like e.g., a determiner slot, can be regarded as a legitimate instance of grammaticalization is highly controversial (see Traugott 2003, 2006; Noël 2007), it is currently acknowledged that a proper understanding of language change has to take into account the driving force of lexically underspecified constructions (Bybee 2003, 2007; Traugott 2006). The emergence of a determiner projection as it is sketched in this paper may then serve as a prime example of this kind of grammaticalization, resulting in abstract constructions.

\subsection{Motivation for the "lexical diffusion"}

As was demonstrated in Sections 4.1-4.5, the shift from modifier to determinative did not come about simultaneously for all different lexeme classes: demonstratives acquired their new status earlier than possessives. Possessives shifted earlier than demonstrative manner pronouns, which themselves preceded demonstrative manner adjectives and anaphoric adjectives. One may wonder whether this order is merely coincidental, or whether there is a deeper motivation for it.

The chance nature of this relative order becomes less likely if it is observed in other languages that have developed a determiner function as well. While typological data from historically unrelated languages would be welcome to endorse such a claim, a quick look at the English facts suggests that the order of the development in Dutch might apply to other languages as well. In present-day English, possessives meet more 
Table 6. English Determinatives

\begin{tabular}{llll}
\hline & $\begin{array}{l}\text { Possessive } \\
\text { pronoun } \\
\text { (our) }\end{array}$ & $\begin{array}{l}\text { Demonstrative } \\
\text { manner pronoun } \\
\text { (such) }\end{array}$ & $\begin{array}{l}\text { Anaphoric } \\
\text { adjective } \\
\text { (aforementioned) }\end{array}$ \\
\hline $\begin{array}{l}\text { crit. ii: co-occurrence with determiner } \\
\text { crit. v: occurrence after adjective }\end{array}$ & $*$ & $*$ & $\sqrt{ }$ \\
crit. v: occurrence after num. & $*$ & $*$ & $\sqrt{ }$ \\
crit. iv: predicative use & $*$ & $\sqrt{ }$ & $\sqrt{ }$ \\
\hline
\end{tabular}

Table 7. Token frequency in the 38 million word corpus of INL

\begin{tabular}{lcc}
\hline Words & Frequency & Frequency per million \\
\hline Possessive pron. (ons) & 80262 & 2112 \\
Dem. man. pron/adj. (dergelijk) & 5572 & 147 \\
Anaphoric adj. (voornoemd) & 2229 & 59 \\
\hline
\end{tabular}

determiner criteria than the demonstrative manner pronoun, which itself still meets more criteria than the anaphoric adjective. An overview is given in table $6 . .^{20}$

How can the order of the "lexical diffusion" be accounted for? One motivating factor may be the token frequency of the pronoun/adjective (see Bybee and Hopper 2001 and Bybee 2003 for the role of frequency in language change). Although the exact proportions may have been different in previous periods, in Present-day Dutch, possessives are more frequent than demonstrative manner pronouns/adjectives, which are themselves more frequent than anaphoric adjectives. ${ }^{21}$

It may be objected, however, that the frequency difference between say demonstrative manner adjectives and anaphoric adjectives is the result, rather than the cause of their earlier shift to the determiner position. In other words: it is not unlikely that e.g., the use of dergelijk 'suchlike' as a determiner has boosted its token frequency. Furthermore, the relation between token frequency and determiner shift is not perfect: some of the incipient determiners in Section 4.5, like e.g., ander 'other' have a higher token frequency than e.g., the anaphoric adjectives in Section 4.4.

The order in which pronouns and adjectives become determinative may alternatively be explained by semantic factors. It seems that the "early" determinatives, like possessives, demonstrative manner pronouns/ adjectives, and anaphoric adjectives can be brought under focus or negation, whereas this is more awkward for some of the incipient determinatives in Section 4.5. Again, there is no perfect correspondence: some 
of the adjectives discussed in Section 4.5 are perfectly able to be focused or negated. A comprehensive account of this matter awaits further research.

\section{Conclusion}

The main thrust of this article is to show that the determiner is not a universal syntactic category, but is diachronically emergent. In the Germanic languages, it first cropped up in the NP in Old Dutch (and Old English, Old High German etc.), and in the subsequent periods more and more elements were recruited as fillers of this new slot. The latter development proceeds through lexical diffusion: not all lexemes converted from modifier to determinative at the same time. With well-known determinatives, like demonstratives and possessive pronouns, the shift was more or less complete before the start of the Modern Dutch period. With minor determinatives, like the demonstrative manner pronoun zulk 'such', the shift did not come to completion until the 20th century. Even more obscure determinatives, like demonstrative manner adjectives (e.g., dergelijk, 'suchlike') and anaphoric adjectives (e.g., voornoemd, 'aforementioned'), are still in transition at present. Sundry other adjectives, like ander 'other', gebruikelijk 'usual', tegengesteld 'opposite' etc., have only hesitatingly started to make the shift to the class of the determinatives.

The upshot of Section 3 and the detailed analyses in Section 4 is that the emergence and accretion of the determiner projection in the NP is the underlying cause, rather than the epiphenomenal result of the array of lexically specific instances of grammaticalization that feature separately in scholarly studies (if they have been subject of research at all). Only if the diachrony of various determinatives is examined together, a coherent picture arises. The elusive syntax of Dutch adjectives and pronouns like dergelijk 'suchlike' en voornoemd 'aforementioned', which remains unexplained in reference grammars of Dutch, falls neatly into place: they are currently undergoing a transition from modifier to determinative, in much the same way as possessive pronouns once were. The combination of quantitative corpus inquiry and a considerate choice of syntactic criteria to distinguish modifiers from determinatives allows us to pin down how far each pronoun/adjective has progressed in this transition.

In Section 5, the emergence of the determiner projection is linked with the ubiquitous diachronic process of grammaticalization, and parallels are drawn with the situation in English. In this way, it is shown that the drastic change in the Dutch NP as it is empirically investigated in this 
paper is not peculiar to Dutch, but ties in with changes in other syntactic domains and other languages.

Received 12 July 2006

University of Leuven

Revised version received

30 May 2007

\section{Appendix. Corpora}

$\mathrm{INL}=$ Instituut voor Nederlandse Lexicologie [Institute for Dutch Lexicology] 38 million-word corpus (http://www.inl.nl).

MNW $=$ Verwijs, Eelco \& Jacob Verdam. [1885-1952] 1998. Middelnederlandsch Woordenboek. The Hague: Sdu [CD-rom].

OED $=$ Oxford English Dictionary (http://dictionary.oed.com).

WNT $=$ De Vries, Matthias \& Lammert A. Te Winkel. [1882-1998] 2003. Woordenboek der Nederlandsche taal. The Hague: Sdu [Cd-rom].

\section{Notes}

* Correspondence address: Dept. of Linguistics, University of Leuven, Blijde Inkomststraat 21, P.O. Box 3308, 3000 Leuven, Belgium. E-mail: Freek.VandeVelde@arts. kuleuven.be.

1. Terminology varies greatly. Instead of determiner, Systemic Functional Grammar (Halliday 1994) prefers the term deictic; Cognitive Grammar (Langacker 1991) associates determiners with the functions of instantiation and grounding; Functional Grammar (Dik 1997; Rijkhoff 2002) speaks of locality operators. Instead of adjunct, terms like epithet (Halliday 1994), type specification (Langacker 1991) or quality satellites (Dik 1997, Rijkhoff 2002) are encountered as well. This list by no means exhausts all extant terms.

2. I will not dwell on the issue which element should be regarded as the head of the whole complex (the so called NP/DP-hypothesis, see Abney 1987; Hewson 1991; Hudson 2004; Van Langendonck 1994; Van Eynde 2006). Neither is the representation under (2) to be taken as a theoretical position with regard to such theory-specific notions as specifiers and different bar levels. Third, the representation in (1) does not show that Mod and $\mathrm{N}$ can be taken together as nominal (the NP in current formal linguistic theory) before they combine with the determiner.

3. Contrary to Payne and Huddleston (2002) I shall not assume that determinatives can also function as adjuncts, or that modifiers can also function as determiners. In other words: the terms determinative and modifier are merely used as shorthand expressions for the terms determiner slotfiller and adjunct slotfiller. These shorthand expressions are convenient for describing the change in syntactic behavior of soms adjectives and pronouns: they switch from the modifier to the determinative class.

4. A distinction should be made between identifying (equative, specificational, extensive ...) predicates (e.g., This is John) and characterizing (ascriptive, classificational, 
intensive ...) predicates (e.g., He is sick). Determinatives are only excluded from the latter: only the characterizing predicates ascribe a property and are hence incompatible with the functional, rather than lexical semantics of the determinative.

5. A suspicious exception is the use of the demonstrative as a predicate that anaphorically refers to a property, as in (the perhaps somewhat outdated?) 1886 example $A$ gentleman?... That he is, from head to foot (OED, s.v. head). Perhaps such use should be treated as an echo. Moreover, it is to be noted that the construction deviates from regular copular clauses, in that the predicate must be fronted $(*$ he is that).

6. As the morphological analysis is not immediately relevant here, glossing is kept simple. RP stands for relative particle. Dutch data are grouped into four periods: Old Dutch (500-1200); Middle Dutch (1200-1500); Modern Dutch (1500-1900) and Present-day Dutch (1900-present).

7. The pattern is - to the best of my knowledge - not attested. Still, in view of the rather scarce Old Dutch data, the absence of the pattern could be coincidental. Some caution is in order here.

8. An Old Dutch example may be seszogh sint thero kuniginnan 'sixty are the queens' (van der Horst 2008: 189), but this is not an entirely straightforward example, as thero kuniginnan is a genitive, which could be considered as a dependent of seszogh.

9. I have not systematically examined all possessive pronouns in the WNT citations. A query was run only on the possessive pronoun ons 'our') in all inflectional forms, in a subsection of the WNT citation material, namely the citations under the lemmas starting with the letter $c$ (the result of a random choice). Instances of "adjunct" use are those in which the possessive pronoun is preceded by a determinative (criterion II); instances of "determiner" use are those in which the possessive pronoun is used without another determinative.

10. The Fisher's Exact Test shows that the distribution in table 1 is not random. The Table Probability $(\mathrm{P})$ indicates the chance that this table would have been generated by coincidence. The Probability (Pr) is the accumulated probability of this table and all tables that are even less likely to occur by coincidence. Here, it is smaller than 0.001 , indicating high significance. The Gamma test measures association between ordinal variables. (The dependent variable is ordinal, as determiners are more subjectified than adjectives, see below). Values range from -1 (strong negative association), over 0 (no association) to +1 (strong positive association). ASE stands for Asymptotic Standard Error, which is multiplied by 1.96 and then added to and subtracted from the Gamma value to yield a $95 \%$ confidence interval. If this interval contains the value 0 , then no association can be assumed. The results here show a strong positive correlation, meaning that determiners are associated with more recent periods, supporting the hypothesis of this paper. The choice to put the external variable in the rows, rather than in the columns as convention would have it, is merely due to lay-out considerations. The statistical tests are not sensitive to the choice for columns and rows.

11. Perusal of the whole citation corpus of the WNT (not only the examples s.v. zulk), has yielded an isolated 19th example: Zulk is de heer Ed. V.M. (WNT s.v. werktuigkundige) (lit.: 'Such is (the) lord Ed. V.M.'), but its rarity may indicate that it belongs to a stilted, literary and probably archaic register in the 19th century.

12. To put a limit on the number of hits of (the frequent word) zulk, I have only gone through the lemmas starting with the letter $r$ (the result of a random choice).

13. The (ubiquitous) attestations with zulk modifying a singular mass noun or plural noun without a demonstrative or article are left out of the counts, because it cannot be unequivocally determined whether they function as determiners themselves, or whether they are preceded or followed by the zero determiner that such nouns normally take. 
Another problem is that an inflected zulk can hide a clitic indefinite article: zulken can either be analyzed as ' $z u l k+$ flexional ending en', or as ' $z u l k+$ indefinite article een'. In either case, an interpretation as an adjunct is ruled out, and these attestations have consequently been counted as determiner uses of zulk (see also following footnote).

14. Zulk is often claimed to be able to act as a "predeterminer", when it precedes the article. However, zulk only precedes a determiner when this determiner is an indefinite article. Other indefinite determiners like enige 'some' or veel 'much' do not occur after $z u l k$. This may indicate that the indefinite article after $z u l k$ is a reinterpretation of an erstwhile inflectional ending. This dovetails with the origin of the construction so beautiful a daughter according to Van der Horst and Van de Velde (2003) (see Section 2.2 above). As the so-called "predeterminer use" is rather suspect, and as it is closer to determiner status than to adjunct status anyhow, I have merged predeterminer and determiner use in the table.

15. A query was run on the demonstrative manner adjectives dergelijk, dusdanig, zodanig and zulkdanig. For zulkdanig and dusdanig, the whole WNT has been run through, for the more frequent dergelijk and zodanig only a subsection was used. For zodanig, I have looked at the citation material under the lemmas starting with $r$ (same material as was used for zulk); for dergelijk, I have looked at the citation material under the lemmas starting with $r$ or $s$ (next letter). As with zulk, the ambiguous hits where a demonstrative manner pronoun precedes a plural or mass noun have been ignored in the counts. Additionally, the construction with an independent demonstrative manner pronoun (that is: not accompanied by a noun) has been ignored, as it seems notably popular in 19th century juridical language, and may skew the results. Due to the rather limited number of attestations in the 20th century, a supplementary query was run on a strictly 20th century corpus, consisting of all issues (1932-2000) of a popular-scientific journal. The total number of hits amounts to 4606, but there are only 268 relevant instances, as the majority of demonstrative manner pronouns occur in indefinite or ambiguous NPs, or are used as an adverb etc.

16. Here, the Chi Square statistic is used, because the expected frequencies per cell are high enough (Fisher's Exact is only resorted to if more than $20 \%$ of the cells have expected frequencies below 5). The distribution is significant using an alpha level of 0.01 . The Gamma measure indicates only a mild association (but it is still significant). This possibly has to do with the fact that the absence of an article in 16th and 17th century instances like (a) may not so much show that the demonstrative manner pronoun is used as a determiner, but rather that the indefinite article was not yet fully obligatory. This is supported by such examples as (b), in which an article is missing to present standards.

(a) Modern Dutch, late 16th century (WNT s.v. rommeling)

$\begin{array}{llllll}\text { in dusdanigen vat (dae sy de Melck in doen...) } \\ \text { in such } & \text { barrel there they the milk in do }\end{array}$

'in such a barrel (in which they put the milk)'

(b) MODERn Dutch, 17th century (WNT s.v. rechthoek)

Rechthoeckigen Driehoeck is, die eenigen rechten hoeck heeft
rectangular triangle is that any right angle has
"A rectangular triangle is one that has a "right angle",

The same goes, by the way, for zulk: its use as a determiner is possibly overestimated in early Modern Dutch. This is corroborated by 16th century examples like (c), in which zulk is at first sight to be analyzed as a determiner judging by the absence of a definite or indefinite article, but which is coordinated with a regular adjective: 
(c) Modern Dutch, latter half 16th century (WNT s.v. remedie)

zulcke ende ghoede remedie

such and good remedy

'such a good remedy'

All this suggests that the figures may in fact be somewhat brighter than they are presented here.

17. See note 4 .

18. Occasional examples of predicative usual do occur in Present-day English. Again, the shift from modifier to determinative is a gradual process, it seems.

19. Of course, the prediction may be complicated by the fact that postdeterminers are morphologically fused with articles, before they become determinatives. If the orthography is in any way indicative, this fusion seems to be the case with English other (yielding another), and with Dutch zelfde 'same' (yielding dezelfde).

20. Some remarks are in order here. First, one could object that English possessives do occur as predicates (e.g., This is mine/yours/...). Note, however, that the possessive takes another form here: it has a derivational suffix that allows it to occur independently. Second, it can be argued that there is one determinative that such is not mutually exclusive with, viz. the indefinite article. But just like in Dutch, the odd syntactic behavior of this construction is historically explicable. Third, the anaphoric adjective aforementioned mostly precedes other adjectives, but not always, as is illustrated in the nice aforementioned extras $(\mathrm{G})$. Fourth, the table does not include manner adjectives.

21. A comparison of the different token frequencies is complicated by the diachronic substitution of the pronoun such by zo'n in Present-day Dutch. Instead of such I have checked the token frequency of the demonstrative manner adjective dergelijke in the 38 million word corpus of INL.

\section{References}

Abney, Steven P. 1987. The English noun phrase in its sentential aspects. Cambridge, MA: Massachusetts Institute of Technology dissertation.

Adamson, Sylvia M. 2000. A lovely little example. In Olga Fischer, Anette Rosenbach \& Dieter Stein (eds.), Pathways of change: Grammaticalization in English, 39-66. Amsterdam: John Benjamins.

Barlow, Michael \& Suzanne Kemmer (eds.) 2000. Usage-based models of language. Stanford: CSLI.

Bernstein, Judy B. 2001. The DP hypothesis: identifying clausal properties in the nominal domain. In Mark R. Baltin \& Chris Collins (eds.) The handbook of contemporary syntactic theory, 536-561. Oxford: Blackwell.

Bolinger, Dwight. 1972. Degree words. The Hague: Mouton.

Breban, Tine. 2003. The grammaticalization of adjectives of identity and difference in English and Dutch. Languages in contrast [special issue] 4(1). 165-199.

Breban, Tine \& Kristin Davidse. 2003. Adjectives of comparison: the grammaticalization of their attribute uses into postdeterminers and classifier uses. Folia Linguistica 37(3/4). 269-317.

Bybee, Joan. 2003. Mechanisms of change in grammaticalization: The role of frequency. In Brian Joseph \& Richard D. Janda (eds.) The handbook of historical linguistics, 602-623. Oxford: Blackwell. 
Bybee, Joan. 2007. Diachronic linguistics. In Dirk Geeraerts \& Hubert Cuyckens (eds.), Handbook of cognitive linguistics, 945-987. Oxford: Oxford University Press.

Bybee, Joan \& Paul J. Hopper (eds.) 2001. Frequency and the emergence of linguistic structure. Amsterdam: John Benjamins.

Coene, Martine \& Yves A. O. D'hulst. 2003. Introduction: the syntax and semantics of noun phrases. In Martine Coene \& Yves A. O. D'hulst (eds.), From DP to NP, vol I: The syntax and semantics of noun phrases, 1-46. Amsterdam: John Benjamins.

Croft, William. 2000. Explaining language change. An evolutionary approach. Harlow: Longman.

Davidse, Kristin 2000. Postdeterminers: Their secondary identifying and quantifying functions. Preprints of the Department of Linguistics 177. Leuven: Department of Linguistics.

Davidse, Kristin, Tine Breban \& An Van linden. 2008. Deictification: The development of secondary deictic meanings by adjectives in the English NP. English Language and Linguistics 12(3). 475-503.

De Grauwe, Luc. 1982. De Wachtendonckse psalmen en glossen. Een lexikologischwoordgeografische studie met proeve van kritische leestekst en glossaria. II. Gent: Secretariaat van de Koninklijke Academie voor Nederlandse Taal- en Letterkunde.

Delfitto, Denis \& Jan Schroten. 1991. Bare plurals and the number affix in DP. Probus 3(2). $155-185$.

Denison, David 2006. Category change and gradience in the determiner system. In Ans van Kemenade \& Bettelou Los (eds.), The handbook of the history of English, 279-304. Oxford: Blackwell.

Dik, Simon C. 1997. The theory of Functional Grammar, part 1: The structure of the clause. Berlin \& New York: Mouton de Gruyter.

Duinhoven, Anton M. 1972. Een de vrijtste ende edelste man vander werlt. De Nieuwe Taalgids 65(6). 441-454.

Duinhoven, Anton M. 1976. Veranderingen in het predicaatsnomen. Leuvense Bijdragen 65(4). 409-435.

Duinhoven, Anton M. 1988. Middelnederlandse syntaxis. Synchroon en diachroon 1. De naamwoordgroep. Leiden: Martinus Nijhoff.

Fischer, Olga 1992. Syntax. In Norman Blake (ed.), The Cambridge history of the English language, vol. II: 1066-1476, 207-408. Cambridge: Cambridge University Press.

Halliday, Michael A. K. 1994. An introduction to Functional Grammar, 2nd edn. London: Arnold.

Harris, Alice C. \& Lyle Campbell. 1995. Historical syntax in cross-linguistic perspective. Cambridge: Cambridge University Press.

Hewson, John 1991. Determiners as heads. Cognitive Linguistics 2(4). 317-337.

Hopper, Paul J. 1987. Emergent Grammar. Berkeley Linguistic Society 13. 139-157.

Hopper, Paul J. \& Elizabeth C. Traugott. 2003. Grammaticalization, 2nd ed. Cambridge: Cambridge University Press.

van der Horst, Johannes M. 2008. Geschiedenis van de Nederlandse syntaxis. Leuven: Leuven University Press.

van der Horst, Johannes M. \& Freek Van de Velde 2003. Zo vreemd een groep Taal \& Tongval (thematic issue) 15/16, 237-250.

Hudson, Richard 2004. Are determiners heads? Functions of Language 11(1). 7-42.

Langacker, Ronald W. 1991. Foundations of cognitive grammar, vol II: Descriptive application. Stanford: Stanford University Press.

Lehmann, Winfred P. 1994. Gothic and the reconstruction of Proto-Germanic. In Ekkehard König \& Johan van der Auwera (eds.), The Germanic languages, 19-37. London: Routledge. 
Longobardi, Giuseppe. 2001. The structure of DPs: some principles, parameters and problems. In Mark R. Baltin \& Chris Collins (eds.) The handbook of contemporary syntactic theory, 562-603. Oxford: Blackwell.

Lyons, Christopher. 1999. Definiteness. Cambridge: Cambridge University Press.

Mitchell, Bruce. 1985. Old English Syntax, vol. I. Oxford: Clarendon Press.

Moerdijk, Alfons 1998. Het WNT in cijfers. In Frans Heyvaert, Alfons Moerdijk, Marijke Mooijaart, Mariëlle Smits \& Rob Tempelaars (eds.), Het grootste woordenboek ter wereld. Een kijkje achter de kolommen van het Woordenboek der Nederlandsche Taal (WNT), 319-338. The Hague: Sdu.

Noël, Dirk 2007. Diachronic construction grammar and grammaticalization theory. Functions of Language 14(2). 177-202.

Payne, John P. \& Rodney D. Huddleston. 2002. Nouns and noun phrases. In Rodney D. Huddleston \& Geoffrey K. Pullum, The Cambridge grammar of the English language, 323-524. Cambridge: Cambridge University Press.

Plank, Frans 1992. Possessives and the distinction between determiners and modifiers (with special reference to German). Journal of Linguistics 28(2). 453-468.

Pullum Geoffrey K. \& Rodney D. Huddleston. 2002. Adjectives and adverbs. In Rodney D. Huddleston \& Geoffrey K. Pullum, The Cambridge grammar of the English language, 525-596. Cambridge: Cambridge University Press.

Quirk, Randolph; Sidney Greenbaum, Geoffrey Leech, \& David Crystal. 1985. A comprehensive grammar of the English language, 2nd edn. London: Longman.

Rijkhoff, Jan. 2002. The noun phrase. Oxford: Oxford University Press.

Schrodt, Richard. 2004. Althochdeutsche Grammatik II: Syntax. Tübingen: Max Niemeyer.

Speelman, Dirk. 1997. Abundantia Verborum. A corpus-tool for carrying out corpus based linguistic case studies. Leuven: University of Leuven dissertation. (http://wwwling.arts. kuleuven.be/genling/abundant/)

Szabolcsi, Anna. 1987. Functional categories in the noun phrase. In Istvàn Kenesei (ed.), Approaches to Hungarian 2, 167-189. Szeged: JATE.

Traugott, Elizabeth C. 1992. Syntax. In Richard M. Hogg (ed.), The Cambridge history of the English language, Volume I: The beginnings to 1066, 168-289. Cambridge: Cambridge University Press.

Traugott, Elizabeth C. 2003. Constructions in grammaticalization. In Joseph, Brian D. \& Richard D. Janda (eds.) The handbook of historical linguistics, 624-647. Oxford: Blackwell.

Traugott, Elizabeth C. 2006. Constructions and language change revisited: The concepts of constructional emergence and coercion from the perspective of grammaticalization. Paper presented at CGN 3, Düsseldorf, April 1-2, 2006.

Tummers, José; Kris Heylen \& Dirk Geeraerts. 2005. Usage-based approaches in cognitive linguistics. A technical state of the art. Corpus Linguistics and Linguistic Theory 1(2). 225-261.

Van Eynde, Frank. 2006. NP-internal agreement and the structure of the noun phrase. Journal of Linguistics 42(1). 139-186.

Van Langendonck, Willy. 1994. Determiners as heads? Cognitive Linguistics 5(3). 243-259. 